Association for Information Systems

AIS Electronic Library (AISeL)

Winter 12-19-2001

\title{
An Exploratory Study And Design of Cross-Cultural Impact on Information Systems Managers' Performance, Job Satisfaction and Managerial Value
}

Hae-Yeon Choi

Follow this and additional works at: https://aisel.aisnet.org/iceb2001

This material is brought to you by the International Conference on Electronic Business (ICEB) at AIS Electronic Library (AISeL). It has been accepted for inclusion in ICEB 2001 Proceedings by an authorized administrator of AIS Electronic Library (AISeL). For more information, please contact elibrary@aisnet.org. 


\title{
AN EXPLORATORY STUDY AND DESIGN OF CROSS-CULTURAL IMPACT ON INFORMATION SYSTEMS MANAGERS' PERFORMANCE, JOB SATISFACTION AND MANAGERIAL VALUE
}

\author{
Hae-Yeon Choi \\ Savannah State University \\ P.O. Box 20359, Savannah, GA 31404 \\ Tel: (912)356-2820 \\ Fax: (912)356-2803 \\ E-Mail: choih@savstate.edu
}

\begin{abstract}
This research is an exploratory study and design to find cross-cultural impact on information systems (IS) managers' performance, job satisfaction and managerial value, particularly on American IS and Korean expatriate IS managers in the United States in the banking industry. Through the literature review, this study attempts to find the most frequently used variables which will be used to measure the magnitude of the cross-cultural impact on those two national IS managers. Finally, this paper presents one research design, which will use the cultural variables to separate the influences of the cross-cultural impact on those IS managers from the other variables.
\end{abstract}

\section{RESEARCH OBJECTIVES}

One of the fundamental issues in cross-cultural management in IS research is to determine the extent culture impacts on IS manager's behaviors, beliefs, attitudes, involvement, values, motivation, commitment, job satisfaction, and performances in the workplace [1]. As the findings of the study shown in Table 1 , "behavior," "value," and "performance" are the variables used very frequently as research variables.

This study will focus on the literature review to find the cultural variables and develop an initial model to conduct a further research with the following objectives:

1. To examine the differences and similarities of the cultural influences on American IS managers and on Korean IS expatriate managers in the U.S.

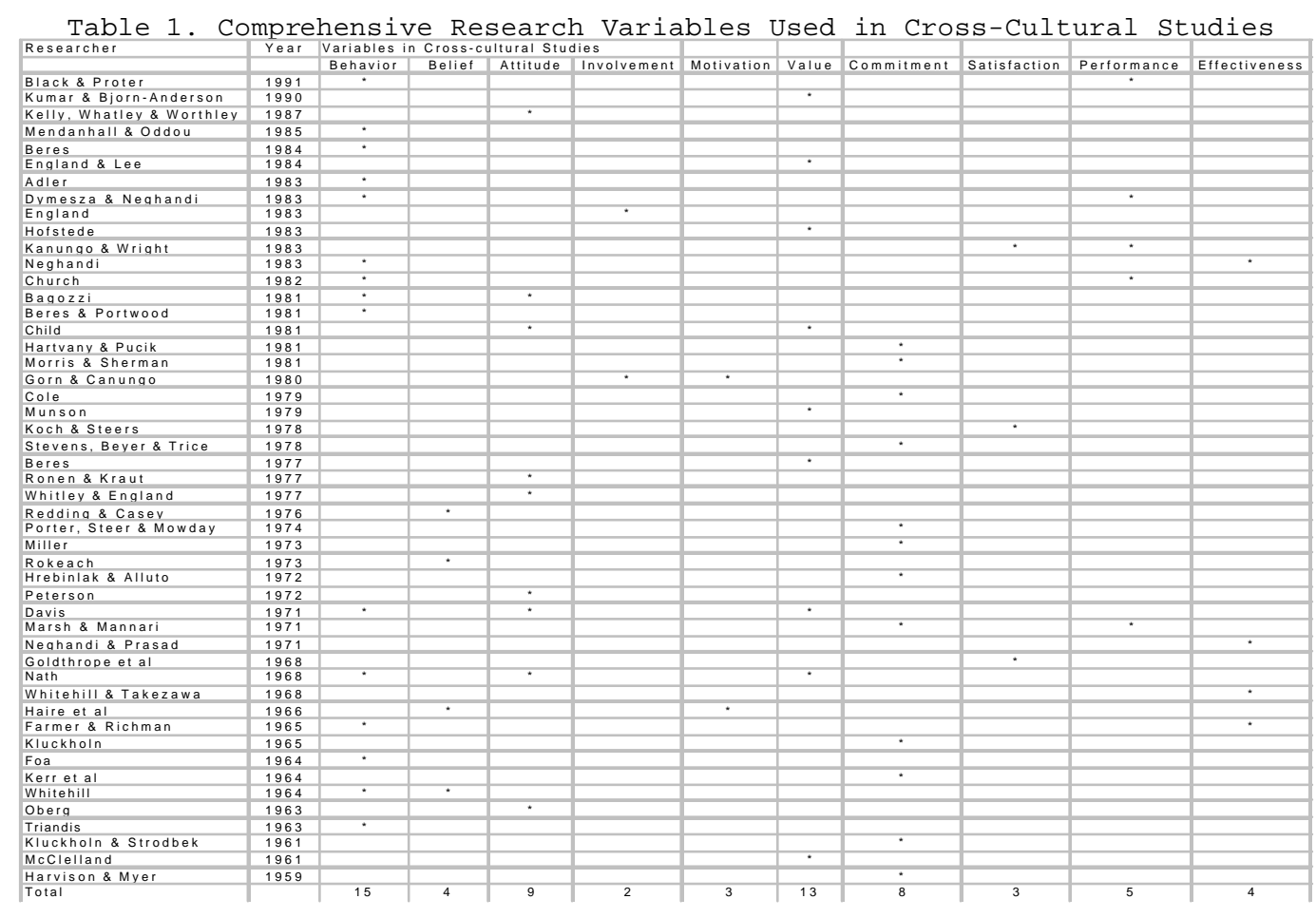

3. To examine Korean IS expatriate managers to determine if they are adapting American managerial practices or if they are enforcing their own culturally oriented policies at the personal level and at the organizational level of their organizations.

\section{LITERATURE REVIEW}

Convergence (or universalist) hypothesis contends that managers are subject to follow industrial norms, attitudes and behaviors in order to comply with the trend of industrialization of the world [45]. Divergence (or culturogist) hypothesis argues that managerial differences will remain permanent around the world as long as differences in culture exist. Child [14] argues that some IS designs in an organization are culture-free while others should be designed for a particular culture if the IS department in an organization is to be effective.

2. To examine the dimensions of the culture between the two groups of IS managers.

The First International Conference on Electronic Business, Hong Kong, December 19-21, 2001. 
As shown in Table 2, convergence perspective by Black and Porter [11], Kerr et al [45], Mendenhall and Oddou [53], Miller [54], Negandhi and Prasad [61] and Tung [74] dominated international management thought during 1950s in the U.S. They believed that international differences in management will disappear as nations of the world "converge" and become equally industrialized and use the same management practices

\begin{tabular}{|c|c|c|}
\hline Distinction & Researchers & Studies \\
\hline \multirow[t]{6}{*}{$\begin{array}{l}\text { Universalists } \\
\text { (Convergence } \\
\text { Hypothesis) }\end{array}$} & $\begin{array}{l}\text { Black \& Porter } \\
(1991)\end{array}$ & $\begin{array}{l}\text { Studied American manager on } \\
\text { assignment in Hong Kong } \\
\text { about managerial behaviors } \\
\text { andits relatedperformances }\end{array}$ \\
\hline & Mendenhal \& Oddou & Managerial behavior is only \\
\hline & Tung (1981) & $\begin{array}{l}\text { Studied ethnic Chinese } \\
\text { managers who have shown to } \\
\text { honor a tight set of rules, }\end{array}$ \\
\hline & Miller (1973) & $\begin{array}{l}\text { Deemphasized the role of } \\
\text { culture in managerial }\end{array}$ \\
\hline & $\begin{array}{l}\text { Neghandhi \& Prasad } \\
\text { (1971) }\end{array}$ & $\begin{array}{l}\text { Deemphasized the role of } \\
\text { culture in managerial } \\
\text { effectiveness }\end{array}$ \\
\hline & Kerr et al (1964) & $\begin{array}{l}\text { Argued that through the } \\
\text { imperatives of } \\
\text { industrialization, value } \\
\text { system of managers become } \\
\text { similar }\end{array}$ \\
\hline \multirow[t]{10}{*}{$\begin{array}{l}\text { Culturogists or } \\
\text { Psychologists } \\
\text { (Divergence } \\
\text { Hypothesis) }\end{array}$} & $\begin{array}{l}\text { Hofstede }(1983, \\
\text { 1981) }\end{array}$ & $\begin{array}{l}\text { Employee value rather than } \\
\text { attitude \& society } \\
\text { comparison rather than } \\
\text { individual }\end{array}$ \\
\hline & $\begin{array}{l}\text { Griffeth, Home, } \\
\text { DeNiShi, \& Kirchner } \\
\end{array}$ & $\begin{array}{l}\text { Different management } \\
\text { attitude studied by }\end{array}$ \\
\hline & $\begin{array}{l}\text { Ruben \& Kealey } \\
(1979)\end{array}$ & $\begin{array}{l}\text { Studied about interpersonal } \\
\text { and communication skills of } \\
\text { expatriates related to } \\
\text { performance }\end{array}$ \\
\hline & Munson (1979) & $\begin{array}{l}\text { Studied cultural } \\
\text { differences based on }\end{array}$ \\
\hline & Bass \& Berger (1979) & $\begin{array}{l}\text { Studied managerial } \\
\text { exercises administered to } \\
5,000 \text { managers for } 13 \\
\text { nations }\end{array}$ \\
\hline & $\begin{array}{l}\text { Whitley \& England } \\
\text { (1977) }\end{array}$ & $\begin{array}{l}\text { Culture and level of } \\
\text { industrialization for } \\
\text { values of managers in five } \\
\text { coluntries }\end{array}$ \\
\hline & $\begin{array}{l}\text { Redding \& Casey } \\
(1976)\end{array}$ & $\begin{array}{l}\text { Studied different beliefs } \\
\text { in dight Asian nations }\end{array}$ \\
\hline & England \& Lee (1974) & $\begin{array}{l}\text { Studied relationship } \\
\text { between values and success } \\
\text { of managers based on } \\
\text { mars' }\end{array}$ \\
\hline & $\begin{array}{l}\text { Farmer \& Richman } \\
\text { (1965) } \\
\text { Haire, Ghiselli \& } \\
\text { Porter (1963) }\end{array}$ & $\begin{array}{l}\text { Studied effectiveness of } \\
\text { countries behaviors as } \\
\text { function of culture } \\
\text { Compared managers among } 14 \\
\text { countries about beliefs, } \\
\text { leadership and motivation }\end{array}$ \\
\hline & McClelland (1961) & $\begin{array}{l}\text { Tested correlation between } \\
\text { need achievement and } \\
\text { entrepreneur endeavor in } \\
\text { five countries }\end{array}$ \\
\hline
\end{tabular}

Table 2. Convergence Versus Divergence Hypothesis

in performance of their managerial duties.

Numerous culturogists or psychologists [6][22][24][29][31] $[36][37][52][57][66][68][76]$ are opposite to the universalists. They viewed that managerial differences will be a permanent characteristic as long as differences in culture exist. Beres and Beres et al [8][9] claimed that the typical measure of cultural values is "methodologically dependent on measures of individual values." On the other hand, Oberg [63] explained that cultures take time to converge and that cultural influences are much stronger. Furthermore, culture is the "most vital" force for diverge nce [67].

There are two general thoughts in the relationship between IS managerial behavior and performance during overseas assignment. One is the cross-cultural school of thought in which Farmer and Richman [25][26] would argue that the effectiveness of a particular managerial behavior is a function of the culture in which the behavior is performed. England and Lee [24] and Whiteley and England [76] examined the relationship between values and success by examining managers from many nations. On the other hand, Negandhi [59] who was the advocate of the practical school of thought assumes that an effective managerial behavior in the U.S. will be effective in foreign countries too. Researchers such as Negandhi and Prasad [61] are the ones who deemphasize the role of culture in managerial effectiveness.

\section{Cultural Variables}

Cultural variables uniquely influence on Korean IS expatriate managers and American IS managers. The commonly used cultural variables in the literature as follows: history [31][50], language [35][77], religion [71][75], political system [39], ethnicity [42], general economic level [32], and geographical propinquity [31]. Dymsza and Negandhi [20] explained that the managerial behaviors of American managers in the U.S., compared to those in a foreign country and compared the relationship between managerial behaviors and job performance in two different contexts. Mendenhall and Oddou [53] explained that even though managerial behavior is not the only determinant of performance, it is an important variable. Lincoln et al [48] have researched cultural differences in the Asian nations' organizations. He found that Confucianism ethic in Korean managers favors vertical social structures, and the vertical differentiation of the organization's structure had positive effects on the personal ties and work satisfaction of the Korean managers. On the other hand, horizontal differentiation had negative effects on personal ties and work satisfaction for Korean managers. Turnover rates are also cited to support it and more committed to their organizations [15]. Steers [69] and Porter et al [65] defined organizational commitment as the relative strength of a manager's identification with and involvement in a particular organization. Other researchers have also found that age is positively relatively related to organizational commitment [38][46][55] in the Asian countries such as Korea. Koch et al [46] and Stevens et al [70] found that tenure such as number of years working in the current position or in an organization has also been found to be positively related to organizational commitment. Therefore, these two variables, age and tenure, have been most frequently examined and have shown that the two variables are most consistent in their relationship to organizational commitment, job satisfaction, and performances.

\section{Motivation and Job Satisfaction}

Successful IS managers of multinational firms are dependent on their performance. Performance of managers, in turn, is

The First International Conference on Electronic Business, Hong Kong, December 19-21, 2001. 
influenced by the rewards which managers desire to have in their work situation and by their perceptions of the degree to which their job expectations are being satisfied [41]. The findings of Kanungo and Wright [41] gave empirical evidence on the job-related values and outcomes. Their findings imply that IS managers' performance is influenced by the levels of their work attitude, motivation and their job satisfaction. As shown in Figure 1, Korean IS expatriate managers' in the U.S. and American IS managers' motivation and job satisfaction are decided by the interaction between the attitude and value which the IS managers have toward their jobs, and values which they have in relation to job outcomes. outcomes are culturally determined mainly with the relative importance of intrinsic versus extrinsic job outcomes.

In their book, Managerial Thinking, Haire, Ghiselli, and Porter [31] studied leadership and the role of the managers in their culture, and satisfaction. They [31] found that those managers in the U.S. and Korea have relatively low homogeneous values. Separating the impact of culture on the development of managerial value in IS is a difficult problem for cross-cultural studies, because the differences in managerial behavior across cultures could be due to culture, to situational contingencies, or to individual differences. Thus, a behavior of managers could be caused by culture, by the situation, or by both of

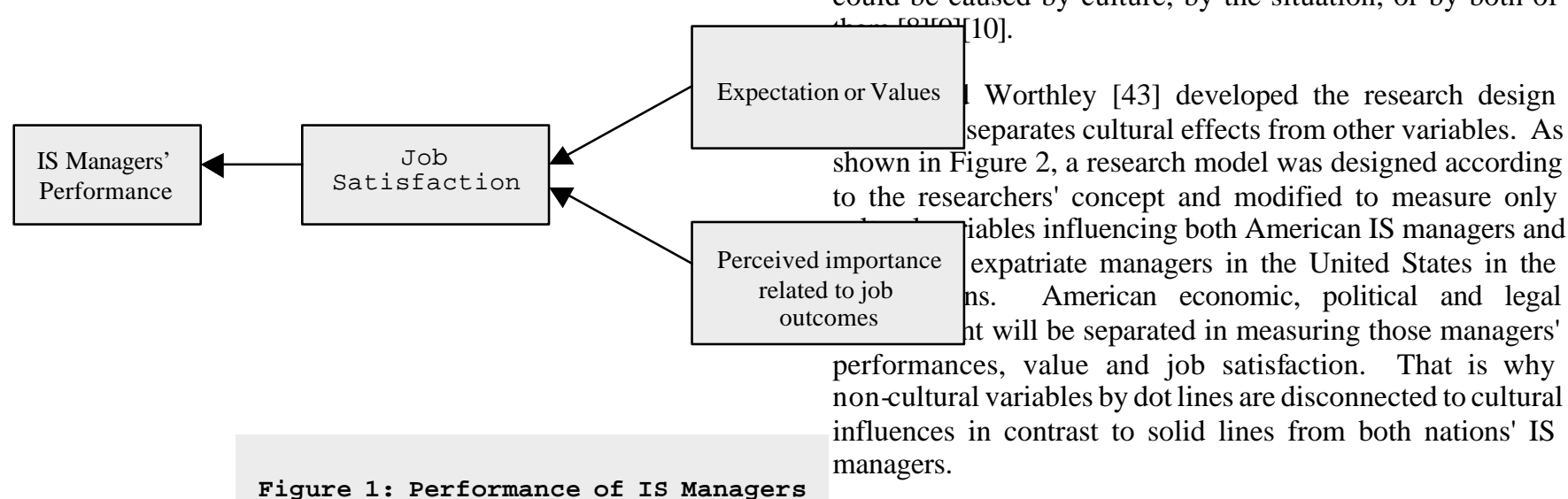

Figure 1: Performance of IS Managers

Recently Kumar and Bjorn-Anderson [47] studied how the values of systems designers in IS have a substantial influence on the extent to which IS meets the effectiveness needs of IS in an organization. An individual manager's personal value [23][24] system makes a difference in terms of how he/she evaluates or perceives information, or how he/she behaves. Therefore, the IS manager's personal or user value system is viewed as a relatively permanent perceptual framework which affects the general nature of the IS managers' behaviors

\section{Explanations for Differences of Managerial Behaviors}

Researchers in the area of cross-cultural studies explained why managers show different behaviors in the different environment. As shown in Table 3, Ajifuruku and Boddewyn [3] explained similarities and differences by using cultural, economic, psychological and sociological variables. These researchers claimed that out of the four variables, cultural variables have substantial influences in managerial behaviors. Harbison and Myers [32] divided managerial similarities and differences into three categories: economical, psychological and sociological. Recently, Gudykunst, Yoon, and Nishida [30] found that Korean managers have a collectivistic culture, and American managers have a very individualistic culture based on Hofstede's study. Hofstede [37] divided national culture into four distinguishable dimensions: power distance, uncertainty avoidance, collectivism versus individualism and masculinity versus feminity. Mulder [56] defined power distance as "the degree of inequality in power between a less powerful individual and a more powerful other." Hofstede [37] found that Korean culture is a family, in which exists the undisputed personal authority of the father-leader, but few

When there is a balance between the job outcomes and the job value or expectations of the IS managers, their levels of job attitude or motivation and satisfaction become higher. On the contrary, if job outcomes do not meet the job expectations of IS managers, their levels of motivation and satisfaction become lower. The values of IS managers of two nations to job 
formal rules, which can be explained as large power distance, and strong uncertainty distance. is similar to the distinction between shame and guilt cultures identified by Ruth Benedict [7]. Other dimensions relevant to motivation are uncertainty avoidance and masculinity-feminity. American society has a willingness to take some risk (weak uncertainty avoidance) and a need to perform, to assert oneself (masculinity), the idea of challenge and achievement.
The distinction between face culture and self-respect culture

situational [2][12][31][64]. In contextual environment, Negandhi [59][60] argued not the cultural specificity, but considered factors such as corporate size , location and market complexity to be at least equally important to a nation's culture. In environmental, Farmer and Richman [25][26] suggested that there are constraints on managerial influence by socioeconomic, political, legal and technical factors. They concluded that managerial practices are functions of external variables.

On the other hand, Nath [58] explained that the behavioral approach explains managerial behavioral patterns. This approachroan be divided as follows:

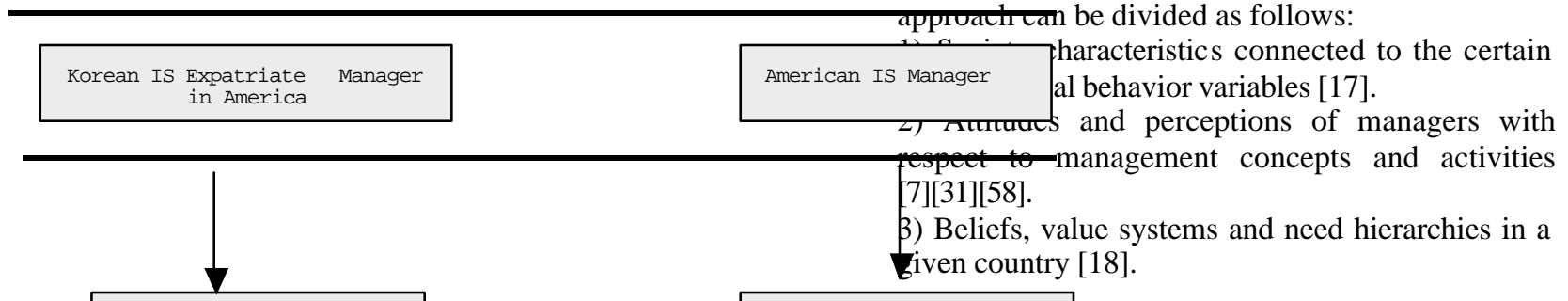

American Cultural ioral approach, attitudes, beliefs, value systems Influences irchies are functions of a given culture of a society. On the contrary, some cross-cultural management researchers claim that there is increasing evidence to support the contention that managerial practices, behavior and ffectiveness are as much, if not more, functions of such American Economic, Political Legal ontextual and environmental variables as they are of
Fnvi ronment ontextual and environmental variables as they are of
ocio-cultural variables [13][59][60]. Finally, Triandis [71][72][73] divided culture into three patterns:

individualism-collectivism, tightness-looseness, and cultural

Figure 2: Research Design for the Isolation of exity. These three forms are explained in relation to the Cultural Influences from Other Variables ing of three aspects of self: private, public, and collective. Morries [52], Lorenz [49], and Eibl-Eibesfeldt [21], Triandis [72] argued that the collective level of mental programming is shared with some other people in a country in a region but not with all other people.

\section{Measurement of Values and Culture}

In this research, values and culture are found to be important variablesi n measuring performance and job satisfaction of the groups of two national IS managers.

Individuals have values and the values can be used to compare individuals. On the other hand, culture compares ethnic groups such as between American and Korean IS managers. The comparison of cultures assumes that there is something to be compared. In other words, there is the distinction between the unique and the comparable, the specific and the general.

Culture includes systems of values; and values are among the building blocks of culture. Some constructs are directly and conceptually related to specific behavior. Fishbein and Ajzen [27][28]] explained that this is particularly the case for intentions, managers' subjective probabilities that they will perform some behavior. On the other hand, other constructs, among which are attitudes and values, are not directly and conceptually related to specific behaviors and these attitudes
Korean societies are masculine but have a strong uncertainty avoidance. That is, Korea is less willing to take risks. Therefore, security is a powerful motivator for IS managers. In other words, Korean IS expatriate managers are very eager to carry out if they are offered security in return. Noburnet al [62] classified four different perspectives: contextual [59][60][61], behavioral [18][36][37][58], environmental [25][26], and
The First International Conference on Electronic Business, Hong Kong, December 19-21, 2001. 
Table 3. Researchers and Their Experimentations for Behaviors

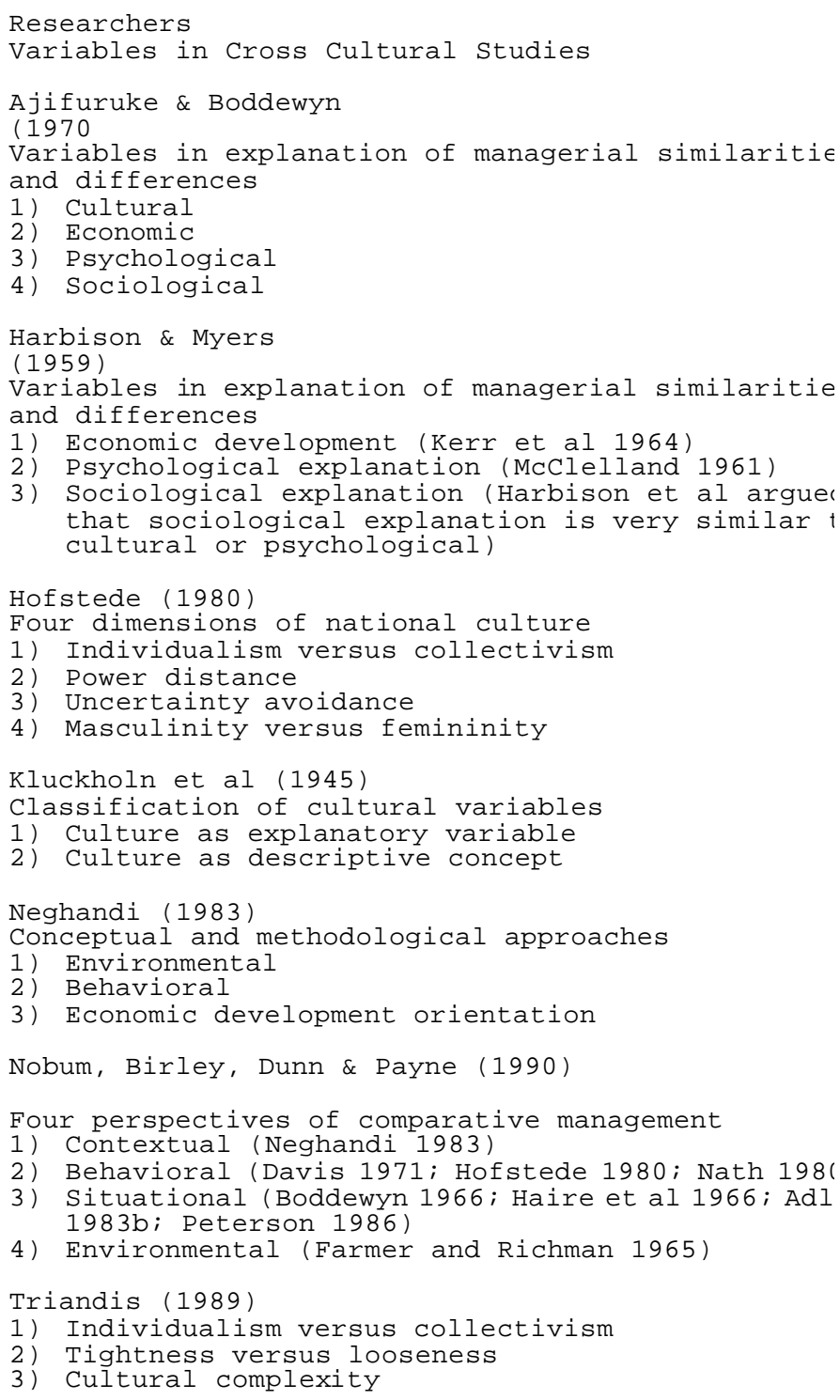

and values and should include construct validation.

The key constructs to be used are values and culture. Values are an attribute of individuals and collectivities. Culture assumes a collectivity. Triandis [71][72][73] and Hofstede [36][37] explained that values have both intensity and direction. The values should further distinguish between values as the desired and the desirable. In this study, culture would be defined as an ethnic group collectivity what personality is as an individual IS manager. On the other hand, personality has been defined by Fishbein et al [27] as "the interactive aggregate of personal characteristics that influence the individual's responses to the environment." Therefore, culture would be one of the main variables used in measuring the behaviors of IS managers.
Cyert and March [17] used the term "uncertainty avoidance". Hofstede [36][37] argued that technology and religion are used to cope with uncertainty. Technology creates short-term predictability as to its outcomes. IS managers in an organization try to make the behavior of people predictable. As suggested by many researchers [36][37][71][72][73], an uncertainty avoidance can be measured on the basis of the country mean score for the three questions such as rule orientation, employment stability and stress.

As Triandis [73] and Hofstede [36][37] suggested, individualism describes the relationship between the individual and the collectivity. In some cultures such as that of the USA, individualism is seen as a blessing and a source of well-being. On the other hand, it is seen as alienating in Korea. Triandis [71][72][73] explained that technologies developed in western individualistic settings more or less presuppose an individualist mentality in entrepreneurs, managers and workers. The collectivist value pattern in more traditional societies sets limit on the technology transfer possibilities. One solution is sought in the transfer of intermediate or appropriate technology which is better adapted to what already exists in the traditional collectivist societies. Another solution is the local design of political and organizational structures which allow collectivism and model technology to coexist. Korea is an example of the successful integration of modern technology with more traditional values. Herzberg etal [34] researched and found that work goals were different depending on the sex (gender). Manhardt [51] similarly found that male workers liked to achieve advancement, responsibility, and supervision of others. Female workers, however, would like to have ample leisure time, good relationship with supervisors, etc. Crowleyet al [16], and Hofstede [37] also had similar findings that male workers wanted to have advancement, higher earnings, and training. On the other hand, female workers wanted to have friendly atmosphere, helping relationships, etc.

There are many researchers [4][19] who have attempted to comprehend the relationship between attitudes and behavior using expectancy-values approaches focused on the relationship between cognition about behavior and the creation of attitudes and/or intentions toward behavior of managers. As shown in Figure 4, these researchers have attempted to examine attitudes towards behavior and that is the expectancy-value formulation [5][40]. These researchers [5][40] studied in job satisfaction to success have an intention to do better performance, productivity, or efforts in their organization. Therefore, this expectancy-value formulation can be applied to measure these objectives of the research using Korean IS expatriate managers and American IS managers.

\section{CONCLUSION}

As an exploratory literature review for cross-cultural related study and design, this research has attempted to determine the extent culture impacts on two national IS managers' values, job satisfaction, and performances in the organization. As shown in Table 1, "behavior," "value," and "performance" are

The First International Conference on Electronic Business, Hong Kong, December 19-21, 2001. 
found to be the variables used very frequently in the literature. Consequently, these variables will be used for further research to measure and explain the cultural influences on Korean IS expatriate and American IS managers in the banking industry. This study also developed a research design for the isolation of cultural influences from other variables to measure the cultural variables only.

\section{REFERENCES}

1. Adler, N. J. "A Typology of Management Studies InvolvingCulture," Lournal of International Business Studies, Vol. 14, No. 2, (1983), pp. 29-47.

2. Adler, N. J. "Cross-Cultural Management: Issues to Be Faced," International Studies of Management and Organization, Vol. 8, Nos. 1-2, (1983), pp. 7-45.

3. Ajiferuke, M. and Boddewyn, J. "Culture and Other Explanatory Variables in Comparative Management Studies," Academy of Management Iournal, Vol. 13, No. 2, (1970), pp. 153-163.

4. Ajzen, I. Attitude Structure and Function, Eribaum, Hillsdale, NJ, 1988.

5. Bailey, J. E. and Pearson, S. W. "Development of a Tool for Measuring and Analyzing Computer User Satisfaction," Management Sciences, Vol. 29, No. 5, (1983), pp. 530-545.

6. Bass, B. and Berger, P. Assessment of Managers: An International Comparison, New York: Free Press, 1979.

7. Benedict, R. The Chrysanthemum and the Sword: Patterns of Japanese Culture, New York, NY: New American Library, 1974.

8. Beres, M. E. "An Historical Concept of C ulture: Advantages and Implications," Paper Presented at the National Academy of Management Meetings, International Management Division, Boston, 1984.

9. Beres, M. E. and Portwood, J. D. Eunctioning of Complex Organizations, Cambridge, MA: Oelgeschlager, Gunn and Hain, 1981.

10. Beres, O. P., Portwood, M. E. and Portwood, J. "Explaining Cultural Differences in the Perceived Role of Work: An Intranational Cross-Cultural Study," An Unpublished Paper Presented at a Cross-Cultural Management Conference, Universty of Hawaii, 1977.

11. Black, J. S. and Porter, L. W. "Managerial Behaviors and Job Performance: A Successful Manager in Los Angeles May Not Succeed in Hong Kong," Inurnal of International Business Studies, Vol. 22, No. 1, (1991), pp. 99-113.
12. Boddewyn, J. Comparative Concepts in Management Administrationand Organization, Graduate School of Business Administration: Mimio, 12, New York, 1966.

13. Boyd, H., Ralph, W. and Stanley, S. Marketing Research-Text and Cases, Homewood, IL: Richard D. Irwin, Inc., 1977.

14. Child, J. D. Research in Organizational Behavior, Greenwich, CT: JAI Publishers, 1981.

15. Cole, R. E. Work, Mobility, and Participation: A Comparative Study of American And Japanese Industry, Los Angeles: University of California Press, 1979.

16. Crowley, J. E., Levitin, T. E. and Quinn, R. P. "Facts and Fictions about American Working Women," In R. P. Quinn \& T. W. Mangione, The 1969-1970 Survey of Working Conditions, Ann Arbor, MI: Institute for Social Research, University of Michigan, 1973.

17. Cyert, R. and March, J. A Behavioral Theory of the Firm Angled, Cliffs: Prentice-Hall. Inc, 1963.

18. Davis, S. M. Comparative Management: Culturaland Organizational Perspectives, Englewood Cliffs, NJ:Prentice-Hall, 1971

19. Dickson, G. W., Desanctis, G. and McBride, D. J. "Understanding the Effectiveness of Computer Graphics for Decision Support: A Cumulative Experimental Approach," Communications of the ACM, Vol. 29, No. 1, (1986), pp. 40-47.

20. Dymsza, W. A. and Negandhi, A. R. "Introduction to Cross-Cultural Management Issue," Iournal of International Business Studies, Vol. 14, No. 2, (1983), pp. $15-16$.

21. Eibl-Eibesfeldt, I. Der Vorprogrammierte Mensch: Das Ererbte Als Bestimmender Faktor in Menschlichen Verhalten, Munchen: Deutcher Taschenbuch Verlag, 1976.

22. Emory, C. W. Business Research Methods, Homewood, IL: Irwin, 1985.

23. England, G. W. "Personal Value Systems of American Managers," Academy of Management Journal, Vol. 10, No. 1, (1967), pp. 53-68.

24. England, G. W. and Lee, R. "The Relationship Between Managerial Values and Managerial Success in the United States, Japan, India and Australia", Iournalof Applied Psychology, Vol. 59, No. 4, (1974), pp. $411-419$.

The First International Conference on Electronic Business, Hong Kong, December 19-21, 2001. 
25. Farmer, R. and Richman, B. "A Model for Resea rch in Comparative Management," California Management Review, Vol. 4, No. 2, (1964), pp. 55-68.

26. Farmer, R. N. and Richman, B. Comparative Management and Economic Progress, Homewood, IL: Irwin, 1965.

27. Fishbein, M. and Ajzen, I. "Attitudes and Opinions," Annual Review of Psychology, Vol. 23, (1972), pp. 487-544.

28. Fishbein, M. and Ajzen, I. Belief, Attitude, Intention, and Behavior: An Introduction to Theory and Research, Addison-Wesley, Reading, MA, 1975.

29. Griffeth, R. W., Hom, P. W., DeNisi, A. and Kirchner, W. "A Multinational Comparison of Managerial Attitudes," Proceedings of Academy of Management Iowrnal, (1980), pp. 63-67.

30. Gudykunst, W., Yoon, Y. and Nishida, T. "The Influence of Individualism-Collectivism on Perceptions of Communication in Ingroup and Outgroup Relationships," Communication Monograph, Vol. 54, No. 3, (1987), pp. 295-306.

31. Haire, M., Ghiselli, E. and Poter, L. Managerial Thinking: An International Study, New York: John Willey and Sons, Inc., 1966.

32. Harb ison, F. H. and Myers, C. A. Management in the Industrial World, New York: McGraw-Hill, 1960.

33. Herzberg, F., Mausner, B., Peterson, R. and Capwell, D. "Job Attitudes: Review of Research and Opinion," Pittsburgh, PA: Psychological Service of Pittsburgh, 1957.

34. Herzberg, F., Mausner, B. and Snyderman, B. B. The Motivation to Work, New York: John Wiley, 1959.

35. Hoebel, A. E., Frost, C. L. and Spencer, A. Cultural and SocialAnthrophy, New York: McGraw-Hill, 1976.

36. Hofstede, G. Culture's Consequences, Beverly hills, CA: Sage, 1980.

37. Hofstede, G. "The Cultural Relativity of Organizational Practices and Theories," Iournal of International Business Studies, Vol. 14, No. 2, (1983), pp. 75-90.

38. Hrebiniak, L. B. and Alluto, J. A. "Personal and Role-Related Factors in the Development of Organizational Commitment," Administrative Science Qwarterly, Vol. 17, (1972), pp. 555-572.

39. Huntington, S. P. "Transnational Organizations in
World Politics," World Politics, Vol 25, No. 1, (1973), pp. 20-35.

40. Ives, B. and Olson, M. "User Involvement and MIS Success: A Review of Research," Management Sciences, Vol. 30, No. 5, (1984), pp. 586-603.

41. Kanungo, R. and Wright, R. W. "A Cross-Cultural Comparative Study of Managerial Job Attitudes," Iournal of International Business Studies, (1983), pp. 115-129.

42. Katona, G., Strumpel, B. and Zahn, E. Aspirations and Affluence, Comparative Studies in the US and Western Europe, New York: McGraw-Hill, 1971.

43. Kelley, L., Whatley, A. and Worhley, R. "Assessing the Effects of Culture on Managerial Attitudes: A Three-Culture Test," Journal of International Business Studies, Vol. 18, No. 2, (1987), pp. 17-31.

44. Kerlinger, F. N.Eoundations of Behavioral Research, McGraw-Hill, New York, 1978.

45. Kerr, C., Dunlop, J., Harbison, F. and Myers, C. IndustrialismandIndustrialMan, 2nd Ed., New York: Oxford University Press, 1954.

46. Koch, J. L. and Allutto, J. "Job Attachment, Satisfaction and Turnover among Public Sector Employees," Iowrnal of Vocational Behavior, Vol. 12, No. 1, (1978), pp. 119-128.

47. Kumar, K. and Bjorn-Anderson, N. "A Cross -Cultural Comparison of IS Designer Values," Communication of the ACM, Vol. 33, No. 5, (1990), pp. 528-538.

48. Lincoln, J. and Gerald, Z. "Organizational Properties from Aggregate Data: Separating Individual and Structural Effects," American Sociological Review, Vol. 45, No. 3, (1978), pp. 391-408.

49. Lorenz, K. On Aggression, New York: Bantam Books, 1970.

50. Malinowski, B. A Scientific Theory of Culture, New York: Oxford University Press, 1960.

51. Manhardt, P J. "Job Orientation of Male and Female College Graduates in Business,"Personnel Psychology, Vol. 25, (1972), pp. 361-368.

52. McClelland, D.The Achieving Society, Princeton, N. J.: D Van Nostrand Company, Inc., 1961.

53. Mendenhall, M. and Oddou, G. "The Dimensions of Expatriate of Acculturation," Academy of Management Review, Vol. 10, No. 1, (1985), pp. 39-47.

The First International Conference on Electronic Business, Hong Kong, December 19-21, 2001. 
54. Miller, J. and Doyle, B. A. "Measuring the Effectiveness of Computer-Based Information Systems in the Financial Services Sector," MIS Quarterly, Vol. 11, No. 1, (1987), pp. 107-124.

55. Morris, J. H. and Sherman, J. D. "Generalizability of an Organizational Commitment Model," Academy of Management Journal, Vol. 24, No. 3, (1981), pp. 512-526.

56. Mulder, M. The Daily PowerGame, Leyden: Martinus Nijhoff, 1977.

57. Munson, M. and McIntyre, S. "Developing Practical Procedures for the Measurement of Personal Values in Cross-Cultural Marketing," Iournal of Marketing Research, Vol. 16, (1979), pp. 48-52.

58. Nath, R. "A Methodological Review of Cross-Cultural Management Research," International Social Science Journal, Vol. 20, No. 1, (1986), pp. 35-62.

59. Neghandi, A. R. "Cross-Cultural Management Research: Trend and Future Directions," Iournal of International Business

Studies, Vol. 14, No. 2, (1983), pp. 17-27.

60. Negandhi, A. R. Modern Organization Theory, Kent, Ohio: Kent State University, 1973.

61. Negandhi, A. R. and Prasad, S. B. Comparative Management, New York: Appleton-Century-Crofts, 1971.

62. Norburn, D., Birley, S. and Dunn, M. "A Four Nation Study of the Relationship Between Marketing Effectiveness, Corporate Culture, Corporate Values, and Market Orientation," Iowrnal of International Business Studies, Vol. 21, No. 3, (1990), pp. 451-468.

63. Oberg, W. "Cross-Cultural Perspective on Management Principles," Academy of Management Iournal, Vol. 6, No. 2, (1963), pp. 141-143.

64. Peterson, R. B. "A Cross-Cultural Perspective of Supervisory Values," Academy of Management Iournal, Vol. 15, No. 1, (1972), pp. 105-117.

65. Porter, L. W., Steers, R. M., Mowdays, R. T. and Boulian, P. V. "Organizational Commitment, Job Satisfaction and Turnover among Psychiatric Technicians," Iowrnal of Applied Psychology, Vol. 59, No. 5, (1974), pp. 603-609.

66. Redding, S. G. and Casey, T. W. "Managerial Beliefs and Behaviors in South East Asia," Working Paper. Hong Kong: Center of Asia Studies, Hong Kong University, 1976.
67. Ronen, S. Comparative and International Management, New York: John Wiley \& Sons, 1986.

68. Ruben, B. and Kealey, D. "Behavioral Assessment of Communication Competency and the Prediction of Cross-Cultural Adaptation," International_Journal of Intercultural Relations, Vol. 3, No. 1, (1979), pp. 15-47.

69. Steers, R. M. and Braunstein, D. N. "A

Behaviorally-Based Measure of Manifest Needs in Work Settings," Iowrnal of Vocational Behavior, Vol. 9, No. 2, (1976), pp. 251-266.

70. Stevens, J. M., Beyer, J. M. and Trice, H. M. "Assessing Personal Role, and Organizational Predictors of Managerial Commitment," Academy of Management Journal, Vol. 21, No. 3, (1978), pp. 380-396.

71. Triandis, H. C. The Analysis of Subjective Culture, New York: John Wiley, 1972.

72. Triandis, H. C. Attitude and Attitude Change, John Wiley, 1971.

73. Triandis, H. C. "The Self and Social Behavior in Differing Cultural Contexts," Psychological Review, Vol. 96, No. 3, (1989), pp. 506-520.

74. Tung, R. "Selecting and Training of Personnel for Overseas Assignments, " Columbia Journal of World Business, Vol. 16, No. 1, 1981, pp. 68-78.

75. Webber, R. A. "Convergence or Divergence?" Columbia Journal of World Business, Vol. 4, No. 3, (1969), pp. 75-83.

76. Whitley, W. and England, G. "Management Values as Reflection of Culture and the Process of Industrialization," Academy of Management Journal, Vol. 20, No. 3, (1977), pp. 439-453.

77. Worf, B. L. Language, Thought, and Reality, New York: Wiley, 1956.

The First International Conference on Electronic Business, Hong Kong, December 19-21, 2001. 